\title{
Chemical Properties and Fatty Acid Composition of Palado Seed Oil (Aglaia sp) Extracted Using Chloroform Solvent
}

\author{
Syamsul RAHMAN ${ }^{1, *}$, Salengke ${ }^{2}$, \\ Abu Bakar TAWALI ${ }^{3}$ and Meta MAHENDRADATTA ${ }^{3}$ \\ ${ }^{1}$ Agribusiness Study Program, Faculty of Agriculture, Universitas Islam Makassar, Indonesia \\ ${ }^{2}$ Department of Engineering Agricultural, Faculty of Agriculture, Hasanuddin University, Indonesia \\ ${ }^{3}$ Departement of Food Science and Technology, Faculty of Agriculture Hasanuddin University, Indonesia
}

("Corresponding author's e-mail: syamrah68@gmail.com)

Received: 9 June 2020, Revised: 7 December 2020, Accepted: 20 December 2020

\begin{abstract}
Palado (Aglaia sp) is a plant that grows wild in the forest around Mamuju regency of West Sulawesi, Indonesia. This plant is locally known as palado. Palado seeds (Aglaia $s p$ ) can be used as a source of vegetable oil because it contains approximately $14.75 \%$ oil, and it has the potential to be used as food ingredients or as raw material for oil production. The purpose of this study was to determine the chemical properties and the composition of fatty acids contained in palado seed oil (Aglaia $s p$ ). The employed method involved the use of palado fruit that had been processed to be palado seed and undergoing flouring process. Palado flour was produced by the extraction process by using chloroform solvent with the soxhlet method. The characteristics of the chemical properties in the oil produced were analyzed by using a standard method, including iodine, saponification, and acid values. The analysis of fatty acid composition was conducted by using gas chromatography. The results showed that palado oil extracted with hexane had an iodine value of $15.38 \mathrm{mg} / \mathrm{g}$, saponification value of $190.01 \mathrm{mg} \mathrm{KOH} / \mathrm{g}$, and acids value of $1.961 \mathrm{mg} \mathrm{KOH} / \mathrm{g}$. The fatty acid composition of the palado seed oil consisted of saturated fatty acids (41.601\%), which included palmitic acid (41.062\%), myristic acid (0.539\%), and unsaturated fatty acids (45.949\%), which included mono-unsaturated fatty acids (MUFA) such as (22.929 \%), oleic acid and poly-unsaturated fatty acids (PUFA), which was linoleic acid (23.020\%).
\end{abstract}

Keywords: Chemical properties, Extracted in chloroform solvent, Fatty acid composition, Palado seed oil

\section{Introduction}

Indonesia is a tropical country with great biodiversity. Indonesian forests are rich of potential sources of edible plants, such as fruits, seeds, and nuts. Palado (Aglaia $s p$ ), locally known as palado in West Sulawesi, is a fruit beeving tropical forest tree. The palado (Aglaia $s p$ ) fruits generally contain 2 seeds rich in carbohydrates and fat. At the national level, the use of palado seeds as food ingredients is far from popular. However, people living around forest area in West Sulawesi have been using the palado seeds as a boiled snack [1].

Palado (Aglaia sp) trees grow well on moist soil. They can live up to 100 years and can reach up to $50 \mathrm{~m}$ in height. These plants only come into fruit-bearing at the age above 10 years. They only bear fruit once a year, bloom in around September and drop their fruits around early February to late March. The fallen fruits are then collected by village dwellers for food. Each tree produces around $250-500 \mathrm{~kg}$ of wet palado fruit for a year [2].

Palado seeds serve as a considerably potential source of food products or as a source of vegetable oil. Research by [1] suggested that palado seed (Aglaia $s p$ ) as a processed product contains crude oil at 
http://wjst.wu.ac.th

around $14.75 \%$ by dry weight. The oil content is relatively larger than the other seeds, such as grape seeds with $12.20 \%$ and pear seeds with $14.10 \%$ [3]. However, the oil content of palado seeds is still lower than the fat of rambutan seed with $17.39 \%$ as reported by [4]. Oil separation from the surrounding tissue using solvent extraction is an important method to extract oil from some types of grains. There have been some reports on tree extraction methods which include blight and dryer, soxhlet, and pressing that are used to extract Clarias microcephalus oil. The best method among these methods is soxhlet since it can produce lipids up to $36.71 \%$, as compared to blight and dryer method that only produces lipids up to $26 \%$ and pressing method is $17 \%$ lipids [5]. On the basis of the separation by using solvent extractions are the differences in solubility of each component in the solids with a solvent [3].

This study aims to determine the chemical properties and composition of fatty acids in palado seed oil (Aglaia sp) which is extracted using chloroform solvent. The portrayal of the seeds of palado is shown in Figure 1.

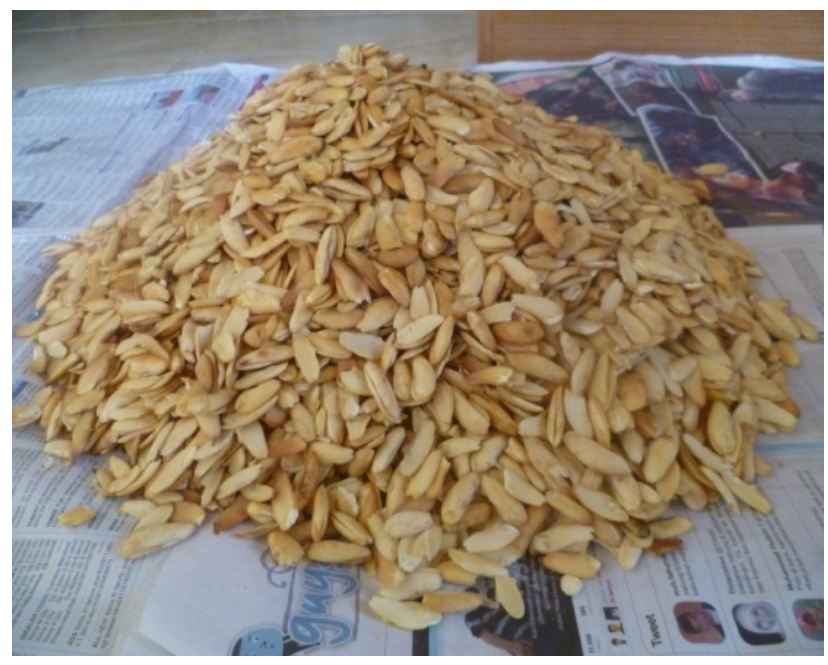

Figure 1 Seeds of palado (Aglaia sp), [6].

\section{Materials and methods}

\section{Material preparation}

The materials used in this study were the Palado fruits (Aglaia sp) collected from forests around the area of West Sulawesi, Indonesia. Palado fruits (Aglaia $s p$ ) as much as $15 \mathrm{~kg}$ were obtained from the forest, then they were sorted out based on the level of intactness. Afterward, the fruits were peeled with simple equipment of small logs to press the tip of the fruit and the board with the size of $20 \times 40 \mathrm{~cm}^{2}$ as its foundation. Then, the peeled palado seeds (Aglaia sp) were dried at a temperature of $30-40{ }^{\circ} \mathrm{C}$ for $40 \mathrm{~h}$ until the beans of palado (Aglaia sp) reached $4.87 \%$ and their water content amounted to $6 \mathrm{~kg}$.

\section{Palado flour processing}

Palado (Aglaia $s p$ ) flour processing was conducted by adopting the methods done by [7], which began with washing the palado seeds, soaking them for 30 min using Sodium bisulphite $0.2 \%$, flour milling using a disc mill Model of AGC 23 (Jakarta, Indonesia), then they were sifted using Tristar 237 (Surabaya, Indonesia) so that the flours produced through a 60 mesh sieve of $250 \mathrm{~g}$. Palado flour (Aglaia $s p$ ) was, then, packaged in a plastic container and stored under dry conditions at room temperature until it was used for further applications. 
http://wjst.wu.ac.th

\section{Palado oil extraction}

Palado oil (Aglaia sp) extraction was conducted by using the method applied by [8] which with some modification. In this method, $100 \mathrm{~g}$ of palado flour (Aglaia $\mathrm{sp}$ ) was extracted using chloroform solvent (bp $40-60{ }^{\circ} \mathrm{C}$ ) for $8 \mathrm{~h}$ in a soxhlet apparatus. Sodium sulfate anhydrite was, then, added to remove residual moisture, then oil was filtered using Whatman No. 1 to produce palado oil (Aglaia sp) of 10.97 $\mathrm{mL} / 100 \mathrm{~g}$ sample with a pale yellow color, which was, later, used for further analysis.

\section{Determination of iodine value}

Iodine value derived from palado oil (Aglaia sp) was determined by the method applied by [9] in which $0.130 \mathrm{~g}$ of oil was put in a conical flask with a stoppered glass sized $500 \mathrm{~mL}$. An empty flask that contained no oil was prepared as well. About $15 \mathrm{ml}$ of cyclohexane and acetic acid solution were mixed in a ratio of $1: 1$, and then added to the flask containing the sample and the empty flask. Then, $25 \mathrm{ml}$ of the oil that had been added to both flasks were closed with a stoppered glass and stirred well. The thermos bottle was left in the dark for $1 \mathrm{~h}$. After that, $20 \mathrm{ml}$ of potassium iodine and $150 \mathrm{ml}$ of distilled water were added to remove iodine from the non-reacted iodine monocloride. Finally, all mixtures were titrated with sodium thiosulfate solution until the yellow color almost disappeared before $1-2 \mathrm{ml}$ starch solution was added as an indicator and titration could be continued. The process ended when the blue color of the starch solution completely disappeared [9].

\section{Determination of saponification value}

The fat of saponification value obtained from palado oil (Aglaia $s p$ ) was determined by the method of AOAC 920.160 [10]. In brief, $2 \mathrm{~g}$ of fat sample was put into a $500 \mathrm{ml}$ sized flask cone. Then $25 \mathrm{ml}$ of sodium hydroxide solution ( $40 \mathrm{~g}$ per 1 liter of $95 \%$ ethanol) was added into the tube, and then the flask was connected to the reflux condenser and heater for $1 \mathrm{~h}$. Then the flask was cooled down in an ice container. Titration was done by adding $1 \mathrm{ml}$ of phenolphythalein (as the indicator) into the mixture and titration was conducted using $0.5 \mathrm{M}$ chloroc acid until the color changed from pink to colorless at the endpoint. A titration control was prepared without adding fat sample and used to determine the saponification value based on this formula;

$$
\text { Saponification value }=\frac{[(\mathrm{BS}) \times 5.28]}{[\text { sample weight }(\mathrm{g})]}
$$

where $\mathrm{B}$ is the volume $(\mathrm{mL})$ of chloric acid needed to control titration and $\mathrm{S}$ is the volume (mL) of chloric acid needed for the titration sample.

\section{Determination of the acid value}

The fat acid value obtained from palado oil (Aglaia $s p$ ) was determined by the AOCS method of Cd3d-63 [10]. In brief, $5 \mathrm{~g}$ of fat was put into a $500 \mathrm{~mL}$ sized cone and added with $50 \mathrm{~mL}$ of ethanol. Then, $50 \mathrm{~mL}$ of phenolphythalein (as the indicator) was added to the mixture and stirred for $20 \mathrm{~s}$. The mixture was titrated with 0.5 of $\mathrm{N}$ potassium hydroxide until the color changes to pink at the end point. The acid value of the sample was calculated as follows;

$$
\text { Acid value }=\frac{(56.1 \times \mathrm{V} \times \mathrm{N})}{[\text { sample weight }(\mathrm{g})]}
$$

where $\mathrm{V}$ is the volume $(\mathrm{ml})$ of potassium hydroxide needed for titration and $\mathrm{N}$ is potassium hydroxide normality. 
http://wjst.wu.ac.th

\section{Chromatography gas analysis of fatty acid}

The fatty acid composition of the oil palado (Aglaia $s p$ ) was determined using chromatography gas of Agilent 6890 (CA, USA) based on the method explained by [10]. Gas chromatography is a system equipped with HP EL-980 with Flame Ionization Detector (FID) and split/separated port injection. Individual FAME separation was reached by the column of HP88 GC $\left(100 \times 0.25 \mathrm{~mm}^{2}\right.$, ID $\left.0.2 \mu \mathrm{m}\right)$. The temperature of GC was set at $125^{\circ} \mathrm{C}$. Then, it was increased to $145{ }^{\circ} \mathrm{C}$ for $8{ }^{\circ} \mathrm{C} / \mathrm{min}$ for 26 min and from $145^{\circ} \mathrm{C}$ for $200{ }^{\circ} \mathrm{C}$ at $2{ }^{\circ} \mathrm{C}$ for $1 \mathrm{~min}$. The injection volume was $1 \mathrm{~mL}$ with a split ratio of 50:1. The detector temperature was set at $260^{\circ} \mathrm{C}$ and a carrier gas was helium $\left(30 \mathrm{~cm} / \mathrm{min}\right.$ at $150{ }^{\circ} \mathrm{C}$ and $\left.303 \mathrm{kPa}\right)$. Chromatography data were recorded using Chemstation software (version 6.0). FAME standard mixture was used for the identification and quantification of the fatty acid composition of the palado oil. Identification of fatty acid methyl ester (James) was done by comparing the retention times of FAME standard and FAME from the sample.

\section{Statistical analysis}

The determination of palado oil (Aglaia $s p$ ) content, iodine value, saponification value and acid value was done in 3 repetitions with the average value, and standard deviation (mean + SD) calculated using Ms. Exel 2010. Meanwhile, the analysis of methyl ester fatty acid composition was done by using gas chromatography that was conducted in 2 repetitions and the average value was not presented.

\section{Results and discussion}

\section{Iodine value}

Iodine value gives the estimated value of unsaturated fatty acids in the triglyceride molecule fats and oils [11]. The amount of absorbed saturated value indicates the value of double bonds/unsaturated bond [12]. Palado oil (Aglaia sp) iodine value obtained $15.38 \mathrm{mg}$ iodine/g, as shown in Table 1. These results are much lower than that reported by [13] on walnut oil iodine value from species of Canarium indicum and Canarium vulgare that were extracted with hexane of 58.63 and $58.38 \mathrm{mg}$ iodine/g respectively. Similarly, the results are comparable to the iodine value of varieties of tea seed oil of Assamica reported by [14] with $83.38-88.89 \mathrm{mg}$ iodine/g.

Table 1 Characteristics of chemical properties of oil palado (Aglaia sp).

\begin{tabular}{lc}
\hline Chemical characteristics & Value \\
\hline Iodine (mg Iodine/g) & $15.380 \pm 0.29$ \\
Saponification $(\mathrm{mg} \mathrm{KOH} / \mathrm{g})$ & $190.010 \pm 1.26$ \\
Acid value $(\mathrm{mg} \mathrm{KOH} / \mathrm{g})$ & $1.961 \pm 1.05$ \\
\hline
\end{tabular}

The high iodine value of oil shows high unsaturated fatty acids in the oil [15]. The decreased iodine value on a dry material allegedly is caused by oxidation in the drying process causing the bound oxygen to the double bonds of unsaturated fatty acids. These processes resulted in reduced oil unsaturation, thereby diminishing iodine value oil [15]. The iodine value serves as an important parameter in the trade that can determine the quality of oil based on the value of double bonds in the fatty acid as revealed by [13]. However, the more double bonds inoil, the easier the oil damage, because it is easily oxidized by oxygen from the air, chemical, or thermal process as indicated by [13]. 
http://wjst.wu.ac.th

\section{Saponification value}

The saponification value is inversely proportional to the molecular weight or average chain length of the fatty acids in oils and fats oils [11]. Likewise, [10] explained that the saponification values can be used to detect the long chain of fatty acids in the oil or fat. This study obtained, the value of saponification of palado oil (Aglaia sp) of $190.01 \mathrm{mg} \mathrm{KOH} / \mathrm{g}$ (Table 1). This result approaches the saponification value of fat cocoa with $190.191 \mathrm{mg} \mathrm{KOH} / \mathrm{g}$ [10], close to the results of [16], which stated that the saponification value of sesame oil (Sesamum indicum L.) is $188-191 \mathrm{mg} \mathrm{KOH} / \mathrm{g}$, and standards results as revealed by[16] which also mentioned the same thing, that the saponification value of sesame oil is $187-195 \mathrm{mg} \mathrm{KOH} / \mathrm{g}$. This fact shows that palado oil saponification value is higher than the saponification value reported by [10] for mango kernel fat of Mangifera pajang and Mangifera indica respectively with 169.70 and $138.15 \mathrm{mg} \mathrm{KOH} / \mathrm{g}$.

Oil that has a lower molecular weight will have a higher saponification value than oil with a high molecular weight [15]. In the dry material and methods of extraction using longer heating and high temperatures, the short-chain free fatty acids will evaporate, leaving the long-chain fatty acids. The longer the chain of free fatty acids is, the higher the molecular weight will be, and thus the lower the saponification oil value is [15].

\section{Acid value}

The value of fatty acids or oils is useful as a parameter to determine the quality of the oil or fat [10]. Likewise, [12] explained that the sum value is a measure of the amount of free fatty acids that are calculated based on the molecular weight of the fatty acids. The acid value is used to determine the level of oil damage. The greater the value of the acid value is, the worse the quality of the oil is. The acid value of palado oil obtained in this study is $1.961 \mathrm{mg} \mathrm{KOH} / \mathrm{g}$, approaching the acid value of cocoa butter reported by [10] which is $2: 11 \mathrm{mg} \mathrm{KOH} / \mathrm{g}$ fat. This acid value indicates a lower value than the acid values reported by [10] for mango fat kernel of Mangifera pajang and Mangifera indica which are respectively 2.81 and $4.77 \mathrm{mg} \mathrm{KOH} / \mathrm{g}$ fat.

The value of palado oil acid value obtained is smaller than the value of cocoa butter acid and mango fatty kernel. This result means that the oil obtained has a good quality [12]. Additionally [17], described the vegetable oil extracted from seeds stored in a long period of time turn out to contain a high acid value. This is due to the combination of lipase enzymes in tissues and enzymes produced by the combination of microbes.

Table 2 The composition of fatty acids in the oil palado (Aglaia $s p$ ).

\begin{tabular}{lcc}
\hline Fatty acid composition & The amount of carbon & Percentage \\
\hline SFA : & $\mathrm{C} 16: 0$ & 41.062 \\
Palmitic acid & $\mathrm{C} 14: 0$ & 0.539 \\
Myristic acid & & 22.929 \\
MUFA : & $\mathrm{C} 18: 1$ & \\
Oleic acid & & 23.020 \\
PUFA : & $\mathrm{C} 18: 2$ & \\
Linoleic acid & & \\
\hline
\end{tabular}


http://wjst.wu.ac.th

\section{Fatty acid composition}

The fatty acid composition of palado seed oil (Aglaia sp) as a result of gas chromatography analysis can be seen in Table 2. The results indicate that palado seed oil contains unsaturated fatty acids (Saturated fatty acid/SFA), which are $41.601 \%$ including palmatic acid $41.062 \%$ and acid myristate $0.539 \%$. Monounsaturated fatty acid (Monounsaturated fatty acid/MUFA) consists of linoleic acid of $23.020 \%$. This result indicates that palado seed oil contains higher unsaturated fatty acids with $45.949 \%$ and saturated fatty acids of $41.601 \%$. In other words, it is still better than the cocoa fatty acid according to the report by [18] that the unsaturated fatty acid is $26.53 \%$ and saturated fatty acids are $69.47 \%(43.23$ $\%$ stearic acid and $26.24 \%$ palmatic acid).

This fatty acid composition of palado seed oil is nearly the same as the fatty acid composition of pumpkin seed oil (Cucurbita maxima Linn.) according to a report by [11] in which unsaturated fatty acid is $55.55 \%$ (40.58\% aleic acid and linoleic acid $14.97 \%)$, while saturated fatty acids is $44.45 \%(27.06 \%$ stearic acid and palmitic acid $17.39 \%$ ). On the contrary, a report by [10] indicated that the fatty acid composition of mango kernel with the varieties of Mangifera indica contains SFA of $51.48 \%$, MUFA of $42.40 \%$, and PUFA of $6.13 \%$, while the fatty acids of mango kernel with the varieties of Mangifera shelf contains SFA of $56.19 \%$, MUFA of $39.24 \%$, and $5.42 \%$. This means that the saturated fatty acids of mango kernel are more dominant than its unsaturated fatty acids. In general, the main component of fatty acid in palado seed oil is palmitic acid of $41.062 \%$, linoleic acid of $23.020 \%$, oleic acid of $22.929 \%$, and myristic acid of $0.539 \%$. The results of this study differ from that reported by [13] regarding the walnut oil (Canarium Indicum) extracted with soxhlet hexane methods in which the highest oleic acid is 45.92 $\%$, followed by palmitic acid with $25.12 \%$, stearic acid with $15.51 \%$, and linoleic acid $12.58 \%$. Likewise, [19] reported the fatty acid composition of Calophyllum inophyllum L. Seed oil with degumming methods resulting in oleic acid of $41.27 \%$, linoleic acid of $33.63 \%$, palmitic acid of 12.23 $\%$, and stearic acid of $11.02 \%$ respectively.

\section{Conclusions}

Oil palado (Aglaia sp) extracted with hexane solvent at a process temperature ranges from $40-60{ }^{\circ} \mathrm{C}$ produces the characteristic of chemical properties including; iodine value of $15.38 \mathrm{mg}$ iodine $/ \mathrm{g}$, saponification value of $190.01 \mathrm{mg} \mathrm{KOH} / \mathrm{g}$, and the acid value of $1.961 \mathrm{mg} \mathrm{KOH} / \mathrm{g}$. Meanwhile, the fatty acid composition produced consists of an SFA of $41.601 \%$ including palmitic acid of $41.062 \%$ and myristic acid of $0.539 \%$, while the unsaturated fatty acids are $45.949 \%$, including MUFA in which oleic acid is $22.929 \%$ and PUFA linoleic acid is $23.020 \%$. This result indicates that the palado oil can be potentially developed as a food ingredient both as a source of nutrition and functional food.

\section{Acknowledgments}

The writers would like to express gratitude to the Ministry of Research and Higher Education of the Republic of Indonesia for funding this Doctoral Dissertation Research, which is a part of the Postgraduate Doctoral Dissertation, University of Hasanuddin Makassar, Indonesia. The writer would also like to extend their thanks to the Laboratory of Research Testing and Postharvest Development Research of Bogor, Testing Laboratory of Department of Industrial Technology of Agriculture, Bogor Agricultural University (IPB), Indonesia, and the Laboratory of the Department of Food Science and Technology IPB for their considerable contribution during the research implementation.

\section{References}

[1] S Rahman. Proximate analysis of palado seed (Aglaia $s p$ ) as an alternative food source locally based. In: Proceedings of the National Association of Food Technologist Indonesia, Jember, Indonesia. 2013, p. 279-88.

[2] S Rahman, S Salengke, AB Tawali and M Mahendradatta. Physicochemical properties of modified palado seed flour (Aglaia sp.) from pregelatinization, cross-linking and acetylation. Pak. J. Nutr. $2019 ; \mathbf{1 8}, 42-50$. 
http://wjst.wu.ac.th

[3] D Larasati and Haslina. Solvent ratio effect on yield and physical carica dieng oil seeds (Carica candamarcencis Hok.). J. Food Technol. Agric. Prod. 2010; 9, 10-5.

[4] W Zzaman, U Issara, NF Febrianto and TA Yang. Fatty acid composition, rheological properties and crystal formation of rambutan fat and cocoa butter. Int. Food Res. J. 2016; 21, 1019-23.

[5] JN Zainuddin, SA Babji and M Said. Extraction of lipids and purification of linoleic acid from Claries microcephalus oil. Aquarium Corservat. Legislat. Int. J. Bioflux 2011; 4, 423-9.

[6] S Rahman, S Salengke, AB Tawali and M Mahendradatta. The chemical contents of the of palado seed (Aglaia sp.) with pregelatinization, cross-linking, and acetylation modifications. Int. j. sci.: basic appl. res. 2017; 32, 305-16.

[7] ABM Hanim, NL Chin and YA Yusof. Physico-chemical and flowability characteristics of a new variety of Malaysian sweet patato, vitAto flour. Int. Food Res. J. 2014; 21, 2099-107.

[8] S Girmay, A Dekebo and RK Bachheti. Fatty acid, metal composition, nutritional value and physicochemical parameters of Lepidium sativium seed oil collected from Ethiopia. Int. Food Res. J. 2016; 23, 827-31.

[9] M Roaini, T Ardiannie and H Norhayati. Physicochemical properties of canola oil, olive oil and palm olein blends. Int. Food Res. J. 2015; 22, 1227-33.

[10] A Azlan, AR Aznira and HE Khoo. Chemical properties and fatty acid composition of Mangifera pajang and Mangifera indica kernel fats. Malays. J. Nutr. 2015; 21, 355-63.

[11] A Habib, MS Biswas, MAH Siddique, M Manirujjanman, B Uddin, MS Hasan, MMH Khan, M Uddin, MM Islam, M Hasan, M Rahman, M Asaduzzaman, MS Rohman, M Khatun, MA Islam and M Rahman. Nutritional and lipid composition analysis of pumpkin seed (Cucurbitamaxima Linn.). J. Nutr. Food Sci. 2015; 5, 1-6.

[12] A Arlene, I Suharto and B Susatio. The influence of the ratio of the feed to the solvent and the temperature in the extraction of oil seeds of hazelnut in the bath to the acquisition of seed hazelnut oil (Aleuritas moluccana). In: Proceedings of the $7^{\text {th }}$ National Symposium Papers Engineering and Industrial Design Applications, Surakarta, Indonesia. 2009, p. 74-9.

[13] GSS Djarkasi, S Raharjo, Z Noor and S Sudarmadji. Physical and chemical properties of Canarium oil. J. Agritech. 2007; 27, 165-70.

[14] S Prasetyo, S Malik and R Wangsadimaja. The effect of temperature roasting and pressing the frequency of using hydrolic press to the quality and quantity of tea seed oil. In: Proceedings of the National Symposium Papers Engineering and Industrial Design Applications, Surakarta, Indonesia. 2009, p. 92-8.

[15] Murtiningrum, S Ketaren, Suprihatin and Kaseno. Oil extraction with wet rendering method of pandanus fruit (Pandanus conoideus L.). J. Agri. Prod. 2005; 15, 28-33.

[16] S Handajani, JG Manuhara and KBR Anandito. Effect of extraction temperature on physical, chemical and sensory characteristics of virgin sesama oil (Sesamum indicum L.). J. Agritech. 2010; 30, 116-22.

[17] NA Widynastuti and B Susilo. Study of heat variation on kelor seed (Moringa oleifera) oil processing using hydrolic press extraction. Bioprocess J. Trop. Commod. 2013; 1, 48-55.

[18] D Indarti and Haslina. Solvent ratio effect on yield and physical process cocoa beans. Chem. Environ. Eng. J. 2007; 6, 50-4.

[19] S Hasibuan, Sahirman and NMA Yudawati. Physicochemical and antibacterial properties of degummed Calophyllum inophyllum L. seed oil. J. Agritech. 2013; 33, 311-9. 